\title{
Local Community and Tourism Development: A Study of Rural Mountainous Destinations
}

\author{
Mastura Jaafar ${ }^{1}$, Norjanah Mohd Bakri ${ }^{1} \&$ S. Mostafa Rasoolimanesh ${ }^{1}$ \\ ${ }^{1}$ School of Housing, Building, and Planning, Universiti Sains Malaysia, Penang, Malaysia \\ Correspondence: S. Mostafa Rasoolimanesh, Post- Doctoral Fellow, School of Housing, Building, and Planning, \\ Universiti Sains Malaysia, Penang, Malaysia. Tel: 604-653-5278. E-mail: mostafa@usm.my
}

Received: December 24, 2014

Accepted: January 14, $2015 \quad$ Online Published: July 30, 2015

doi:10.5539/mas.v9n8p399

URL: http://dx.doi.org/10.5539/mas.v9n8p399

The research is financed by the Ministry of Higher Education, Malaysia under the Long-Term Research Grant Scheme 2011 [LRGS Grant No. JPT.S (BPKI)2000/09/01/015Jld4(67)].

\begin{abstract}
Malaysia is internationally regarded as a popular rural destination because of its natural heritage. Rural tourism is increasingly viewed as a panacea for increasing the economic viability of marginalized areas, stimulating social regeneration, and improving the living conditions of rural communities. This study explores local community involvement in a rural tourism development in Kinabalu National Park, Sabah. We explore how the local community perceives their involvement in a local rural tourism development and look to identify the benefit of tourism destination development for this community. To address these objectives, we employed quantitative research methodologies and a sample of 378 respondents drawn from villages surrounding Kinabalu National Park. Sampled residents indicated having positive perceptions of tourism development in the area. Local communities enjoy being involved in the tourism sector because it improves their key income resources and quality of life.
\end{abstract}

Keywords: rural tourism, local community, community involvement, mountainous destinations, kinabalu national park

\section{Introduction}

Rural tourism has attracted renewed interest from researchers. In defining rural tourism, Lane (1994) notes several defining characteristics, such as a destination located in a rural area, functionally rural, small-scale, traditional, and largely locally controlled. Top rural tourism destinations, particularly in developing countries, normally consist of national parks, wilderness areas, mountains, lakes, and cultural sites. Okech et al. (2012) observes that these sites are important features of the rural economy.

Chaudhry and Gupta (2010) report that $75 \%$ of the world's poor live in rural areas and that rural tourism is a tool for rural revitalization. Rural tourism benefits local communities in terms of stimulating economic growth, valuing social cultural heritage, triggering the growth of service industries, and raising the standard of living; these benefits in turn encouraging positive attitudes and behaviors among these communities toward regard to tourism development (Jaafar et al., 2013; Nunkoo \& Gursoy, 2012). Hall (1994) indicates that tourism is a viable means of promoting economic activity in developed and developing countries alike, and that rural tourism often enjoys substantial encouragement from both the public and private sectors (Fleischer \& Pizam, 1997)

Malaysia has great potential in terms of nature tourism and ecotourism (Backhaus, 2003). Khalifah and Tahir (1997) indicate that Malaysia's tropical rainforests are among the oldest and most diverse ecosystems in the world. Covering an area of $753.7 \mathrm{~km}^{2}$, Kinabalu National Park, in Malaysia, first became a national park in 1964. In 2000, the United Nations Educational, Scientific, and Cultural Organization (UNESCO) designated Kinabalu National Park a World Heritage Site (WHS). National parks function for the preservation of natural habitats and wilderness areas; however, they also facilitate educational, recreational, and tourism access. Consequently, the state government of Sabah has undertaken a series of initiatives to position Kinabalu Park as an international attraction and to encourage the local community to participate in its development. These initiatives, Liu (2006) suggests, demonstrate the government's use of rural tourism a mechanism for racial and spatial economic 
restructuring to reduce regional disparities and to increase the economic control of the indigenous Bumiputra people.

Studies of rural tourism remain in their infancy, an opinion shared by Frederick (1993). While Suh and Gartner (2004) argues that tourism in peripheral areas has been extensively investigated, a review of the rural tourism literature reveals that disproportionately less attention has been afforded to rural tourism as compared to other forms of tourism; furthermore, tourism would appear to have been largely been ignored by rural economists. The rural tourism studies that do appear in the literature are diverse, indicative of a lack of focus in the area. For instance, Liu (2006) analyzes the socio-economic effect of tourism based on local participation in the tourism industry. Scheyvens (2002) investigates the participation of local communities in the decision-making processes, whereas Lacher and Nepal (2010) examine the participation of minority groups in the tourism industry. However, few studies have investigated the economic distribution of the benefits of tourism across a local community (Harrison \& Schipani, 2007).

Researchers have rarely examined the economic advantages of mountain tourism in Malaysia. Most Malaysian highland studies have focused on the physical and social effects of mountain tourism, such as the effect on the diversity of small mammals on Mount Kinabalu (Shukor, 2001), community land and forest management systems (Horowitz, 1998), or the ecology (Maryati et al., 1996). Only two studies (Hasegawa et al., 2006; Liu, 2006) have correlated rural tourism in Malaysia with economic development. In view of this knowledge gap, the following research questions are posed:

1. To what extent is the local community involved in the development of rural tourism in Kinabalu Park?

2. How does the local community benefit from tourism development?

To answer these research questions, we undertake an extensive review of the literature concerning rural tourism and local community involvement in the tourism sector. In describing our methodologies, we give an account of our sampling procedures. In the results section, we describe the characteristics of our sample, their level of involvement in the tourism sector, and what benefits community members receive from tourism. Before concluding this paper, we undertake a discussion of the findings of this study in relation to previous studies.

\section{Literature Review}

Various efforts have been made to explain the key elements of rural tourism. Keane (1992) and Sharpley (2000) characterize rural tourism in terms of the destination's attractiveness to a type of tourist who enjoy unique or themed experiences exhibiting qualities of peace, relaxation, inspiration, recreation, local culture, and entertainment. Sharpley and Sharpley (1997) suggest that the sense of space, peace and tranquility, and escape from modern pressures are qualities which are intrinsic to rural tourism. In this century, however, researchers have come to view rural tourism from a wider perspective. For example, Macdonald and Jolliffe (2003) refer to rural tourism as a tool for the development of rural and isolated areas and as facilitating the growth of traditional industries. Eruera (2008) propose that rural tourism encompasses a wide range of activities, natural or man-made attractions, amenities and facilities, transportation, and marketing and information systems. While Ghaderi and Handerson (2012) associates low population density and minimal land area usage - providing tourists with an impression of space - with rural tourism.

The International Year of Mountains, in 2002, was a unified response to increased global awareness of mountain and tourism issues (Nepal \& Chipeniuk, 2005). Mountain regions have high levels of both ecological and cultural diversity (Stepp, 2000), and Lama and Sattar (2002) argue that tourism is vital for the conservation and development of these highland regions. Highlands are rich in natural resources, including water, timber, minerals, biodiversity, and cultural heritage, making them attractive tourism destinations (Beedie \& Hudson, 2003). Consequently, highland tourism has developed rapidly worldwide in recent decades (Moss \& Godde, 2000), constituting $15-20 \%$ of worldwide tourism or US\$70-90 billion per year, and has become a significant influence on the economies of many countries (Lama \& Sattar, 2002).

\subsection{Importance of Rural Tourism}

Tourism is a means to stimulating local economic development (Gurung \& DeCoursey, 2000). In Europe and elsewhere, rural tourism provides economic and social benefits to rural destination communities (Iorio \& Corsale, 2010). Sharpley (2000) observes that rural tourism can act as a catalyst for socio-economic development and regeneration. Furthermore, rural tourism can supplement the incomes of impoverished agricultural cooperative settlements (Fleischer \& Pizam, 1997), and provide new sources of income for families living in remote rural areas (Gale, 2006; Su, 2011).

Tourism contributes toward rural development because it provides another avenue for employment and income 
generation, expands the market for local products, and revitalizes traditional economies (Azman et al., 2011; Ghaderi \& Henderson, 2012). Hall (2004) notes that rural tourism benefits local communities by providing a supplementary income to the farming, craft, and service sectors. Hall (2004) also observes that rural tourism allows the economic value local food products to be reassessed, especially higher quality products which might otherwise escape special attention, and that rural tourism provides the opportunity to re-evaluate local heritage and its symbols, environment, and identity.

\subsection{Community Participation and Rural Tourism}

Thongma et al. (2011) suggest that the involvement of local communities is instrumental to the success of rural tourism development because these communities build more personable relationships wih visiting tourists and impress visitors with local cultural activities. Consequently, having had an enjoyable experience during their visit, the visitors leaves satisfied and more likely to revisit the same destination (Lo et al., 2013). Furthermore, local community participation provides locals with opportunities to enjoy the benefits of the development activities and empowers them to mobilize their capabilities through small business ventures (May-Ling et al., 2014). Therefore, the participation of the local community in rural tourism is a positive force for change and a catalyst for development (Claiborne, 2010).

Community participation need not necessarily be direct, as noted by Telfer and Sharpley (2007). For example, community participation can often focus on the decision-making process and non-economic benefits of tourism development (Tosun, 2000). Only when local communities are involved in decision making can their benefits be ensured, and their traditional lifestyles and values respected (Sheldon \& Abenoja, 2001).

In the context of tourism planning, community participation can be defined thusly: "A process of involving all [stakeholders] (local government officials, local citizens, architects, developers, business people, and planners) in such way that decision-making is shared" (Okazaki 2008, p. 511). Scheyvens (1999) argues that the host community should be involved in tourism planning because they (a) have a historical understanding of how the region adapts to change, (b) are the ones most closely affected by tourism, and (c) are expected to become an integral part of the tourism product. Consequently, the literature would seem to strongly advocate the position that the sustainability of a tourism development might contingent upon the direct and indirect involvement of the local community (Hall, 2008; Mowforth \& Munt, 2008).

\section{Methodology}

This study investigates the contribution of community involvement to rural tourism development. We used a survey questionnaire to explore the involvement of the local community in rural tourism development and to identify the what tourism development benefits the local Kinabalu National Park community in Sabah were recipients of. Stratified random sampling was used to distribute the questionnaire among local communities around Kinabalu National Park; these communities being divided according to districts and villages. The sampling frame (see Table 1) consisted of local residents who lived near the predetermined sampling areas within the vicinity of Kinabalu National Park. Respondents from villages that contributed the most to tourism activities were selected for participation through the recommendation of local authorities, particularly those authorities responsible for Sabah's park management. The respondents included mountain guides, porters, service staff, and hospitality-related workers.

Table 1. Sampling frame

\begin{tabular}{cccc}
\hline Population & Distributed Questionnaires & Returned Questionnaires & Valid Responses \\
\hline 3822 & 450 & 401 & 378 \\
& & $(89.1 \%)$ & $(84 \%)$ \\
\hline
\end{tabular}

Descriptive methods of statistical analysis, including frequency and mean, were used to analyze collected data per the research objectives.

\section{Analysis and Findings}

Of the 378 respondents, $38.6 \%$ were male, and $61.4 \%$ were female. In descending order of frequency, respondents were aged 21-30 (31.7\%), 31-40 (24.3\%), 41-50 (20.9\%), and 51 and above (16.9\%). In terms of their educational background, most of the respondents had some formal education (93.7\%), whereas only a handful had no prior education (6.3\%). Half of the respondents $(54.5 \%)$ attained only a secondary education.

Involvement in the tourism sector among the local communities is shown in Table 2. Data analysis shows that 
most of the respondents were indigenous to the area (74.9\%). Most of the respondents had previous experience in the tourism sector $(68.5 \%)$, although most (52.1\%) had less than 10 years involvement in the industry. Most of the respondents were either self-employed (38.4\%), or employed full-time $(24.6 \%)$. Before working in the tourism sector, most of the respondents were employed in other occupations, mostly mechanics or students $(82 \%)$. The survey also revealed that $32 \%$ of the local community working in the tourism sector earned less than MYR 1080 (approx. US\$ 313 at the time of this writing) per month, 20.9\% earned MYR 1081-2080, and 8.7\% earned MYR 2081-3080. Before being involved in the tourism sector, 42.1\% earned less than MYR 1080 per month, and only $9.3 \%$ earned MYR 4081-5080.

Table 2. Involvement in tourism sector

\begin{tabular}{|c|c|c|c|}
\hline Questions & Scale & Frequency & Percentage\%) \\
\hline \multirow[t]{2}{*}{ Indigenous Population } & Yes & 283 & 74.9 \\
\hline & No & 95 & 25.1 \\
\hline Previous Involvement in & Yes & 258 & 68.5 \\
\hline Tourism Sector & No & 120 & 31.5 \\
\hline \multirow[t]{4}{*}{ Years of Involvement } & $1-10$ & 197 & 52.1 \\
\hline & $11-20$ & 37 & 9.8 \\
\hline & $21-30$ & 20 & 5.3 \\
\hline & $31-40$ & 4 & 1.1 \\
\hline \multirow[t]{4}{*}{ Previous Occupation } & Farmer & 71 & 18.8 \\
\hline & Businessman/Self-employed & 80 & 21.2 \\
\hline & Government employee & 25 & 6.6 \\
\hline & Other & 82 & 21.7 \\
\hline Previous Monthly & Below1080* & 159 & 42.1 \\
\hline \multirow[t]{5}{*}{ Income } & $1081-2080$ & 50 & 13.2 \\
\hline & $2081-3080$ & 8 & 2.1 \\
\hline & $3081-4080$ & 4 & 1.1 \\
\hline & $4081-5080$ & 35 & 9.3 \\
\hline & Above 5081 & 2 & 0.6 \\
\hline \multirow[t]{6}{*}{ Current Monthly Income } & Below 1080 & 121 & 32.0 \\
\hline & $1081-2080$ & 79 & 20.9 \\
\hline & 2081-3080 & 33 & 8.7 \\
\hline & $3081-4080$ & 5 & 1.3 \\
\hline & $4081-5080$ & 6 & 1.6 \\
\hline & Above 5081 & 14 & 3.0 \\
\hline \multirow[t]{5}{*}{ Employment status } & Self-employment & 145 & 38.4 \\
\hline & Employees/Staff & 87 & 23.0 \\
\hline & Part-time worker & 14 & 3.7 \\
\hline & Government worker & 11 & 2.9 \\
\hline & Others & 1 & 0.3 \\
\hline
\end{tabular}

Note: $*$ MYR $3.45=$ USD 1.00

The local communities' sectoral involvement in tourism development is depicted in Table 3. Five tourism sectors; namely, transport, services, food and beverage, handicraft shops, and services and support, were selected. Table 3 categorizes the six tourism-related sectors that involving the local community: transportation, accommodations, food and beverage, handicraft, services, and others. As a service industry, tourism needs support from other industries through a complex chain of supply providing goods and services. Respondents were divided across the food and beverage (20.6\%), accommodation (18.3\%), in handicraft $(11.1 \%)$, and other service $(10.3 \%)$ industries. The "others" sector, comprising only $6.3 \%$ of the sample, included fish farmers, government servants, lifeguards, flower and vegetable stall vendors. 
Table 3. Sectoral involvement

\begin{tabular}{llrr}
\hline \multicolumn{1}{c}{ Involvement sector } & Frequency & Percentage \\
\hline Transportation & Car/van rental & 5 & 1.3 \\
& Taxi driver & 2 & 0.5 \\
Accommodations & & 18 & 4.8 \\
& Hotel/budget hotel & 2 & 0.5 \\
& Apartment/condomini & 49 & 13.0 \\
& um & & \\
& Guest & 17 & 4.5 \\
Food and beverage & room/chalet/homestay & 51 & 13.5 \\
& Bar & 10 & 2.6 \\
& Food stall & & \\
Handicraft shops & Restaurant & 42 & 11.1 \\
& & 3 & 0.8 \\
& Information center & 7 & 1.9 \\
& Grocery store & 1 & 0.3 \\
& Laundry soap & 1 & 0.3 \\
Services & Cyber café & & \\
& Tourist guide & 7 & 1.9 \\
& Site guide & 9 & 2.4 \\
& Mountain guide & 7 & 1.9 \\
& Porter & 1 & 0.3 \\
& Others & 2 & 0.5 \\
Others & Fish farm & 2 & 0.5 \\
& Government servant & 10 & 2.6 \\
& Lifeguard & 2 & 0.5 \\
& Flower stall & 3 & 0.8 \\
& Vegetable stall & 7 & 1.9 \\
\hline
\end{tabular}

Respondents' perspectives on their involvement in rural tourism is presented in Table 4. Seven questions were asked of the respondents to evaluate their perspectives about community involvement in tourism development. These questions were answered along a 5-point Likert scale, from 1 (strongly disagree) to 5 (strongly agree). The highest mean score belonged to, "The local community should be given opportunity in decision making" ( $\bar{x}=$ 3.94). At the opposite end of the spectrum, the lowest score belonged to, "The progress of the local tourism sector is more significantly dominated by outsiders than by locals" $(\bar{x}=3.36)$. These mean scores suggest that the local community is interested in engaging throughout the tourism development.

Table 4. Community involvement in rural tourism development

\begin{tabular}{lll}
\hline \multicolumn{1}{c}{ Items } & Mean & Std. Deviation \\
\hline The local community should be given opportunity in decision making. & 3.94 & 0.859 \\
$\begin{array}{l}\text { The local community has been given an opportunity in giving an opinion. } \\
\begin{array}{l}\text { There is good cooperation between the local community and important } \\
\text { persons (stakeholders). }\end{array}\end{array}$ & 3.65 & 0.975 \\
$\begin{array}{l}\text { Support for tourism development depends on the level of awareness and } \\
\text { knowledge of the local community. }\end{array}$ & 3.82 & 0.958 \\
$\begin{array}{l}\text { The government encourages local community involvement in tourism } \\
\text { activity. }\end{array}$ & 3.92 & 0.846 \\
$\begin{array}{l}\text { The local community should have the authority to control tourism } \\
\text { development. }\end{array}$ & 3.83 & 0.901 \\
$\begin{array}{l}\text { The progress of the local tourism sector is more significantly dominated } \\
\text { by outsiders than by locals. }\end{array}$ & 3.36 & 1.294 \\
\hline
\end{tabular}

Table 5 describes the advantages of tourism development from the perspective of the respondents. The highest mean score was for, "Tourism development can create new business opportunities and can increase household income" $(\bar{x}=4.12)$. As shown in Table 5, the mean value of all the responses were high $(>3.64)$, the mean scores for these items demonstrating that tourism positively affects the life of the local community. The local 
community agree that tourism development gives them a chance to improve their lives, and in turn, they support tourism through entrepreneurial activities.

Table 5. Advantages of tourism development from perspective of community

\begin{tabular}{|c|c|c|}
\hline Items & Mean & Std. Deviation \\
\hline Tourism helps to improve the economic conditions of the local community. & 4.02 & 0.741 \\
\hline Tourism creates jobs and investment appropriate for the local community. & 3.91 & 0.829 \\
\hline $\begin{array}{l}\text { An increase in the number of tourists enhances the economy of local } \\
\text { communities. }\end{array}$ & 4.02 & 0.784 \\
\hline The local community generates greater income from tourism. & 3.64 & 0.931 \\
\hline The local community earns money from selling local products. & 3.95 & 0.788 \\
\hline Tourism development can create new business opportunities. & 4.12 & 0.751 \\
\hline Tourism can increase household income. & 4.12 & 0.723 \\
\hline $\begin{array}{l}\text { Local communities should be given priority in the field of tourism } \\
\text { entrepreneurship. }\end{array}$ & 4.10 & 0.807 \\
\hline $\begin{array}{l}\text { The benefits of tourism to the local community are appropriate in relation to its } \\
\text { costs. }\end{array}$ & 3.72 & 0.841 \\
\hline $\begin{array}{l}\text { Standard of living has increased because of tourist spending in the local } \\
\text { community. }\end{array}$ & 3.84 & 0.840 \\
\hline $\begin{array}{l}\text { Tourism development generates more benefits than losses for the local } \\
\text { community. }\end{array}$ & 3.80 & 0.892 \\
\hline $\begin{array}{l}\text { Tourism development can improve infrastructure, such as roads, electricity, and } \\
\text { schools. }\end{array}$ & 4.05 & 0.877 \\
\hline
\end{tabular}

\section{Discussion}

This paper explored the involvement of local communities in the development of a rural mountain tourism industry and the advantages of that tourism development for the local community in Kinabalu National Park, Malaysia. Situated in the heart of Sabah, almost to the north of Borneo Island, Kinabalu National Park was awarded WHS by UNESCO in 2000 for its outstanding universal value, being a rich source of biodiversity. As a nature-based attraction, it is this biodiversity, more than its local communities, that has captured the attention of researchers. This study sought to identify the perceptions of the local community regarding the tourism development of the surrounding the area.

The data revealed that mountain tourism development was well received by the local community. The majority of the local community, those aged 21-30, had begun their careers in various tourism-related sectors. In light of the general paucity of formal education among the local populace, the tourism sector provided an ideal career option for many. Many of the local youth we surveyed had become involved in the tourism industry 1-10 years ago, within a few years of Kinabalu National Park having been recognized as a WHS. Thirteen years since having been recognized, tourism development in and around Kinabalu National Park has dramatically altered the pattern of community employment, from farming to self-employment, thereby explaining the increased salary of residents as shown in Table 2. This finding supports those of previous studies (Gale, 2006; Gurung \& DeCoursey, 2000; Iorio \& Corsale, 2010; Liu, 2006; Petric, 2003). Ghaderi and Henderson (2012) observed that the benefits of rural tourism include the generation of income and employment, the creation of a market for local products, and the vitalization of usually stagnate traditional economies.

Our analysis of the community's perceptions of tourism development in the area revealed the positive effects that development had had-locals felt that tourism development provided unparallelled opportunities for them to enter new economic sectors. Rural tourism provides a new market to small businesses and encouraged the development of such businesses directly and indirectly. The spinoff of this effect was a more general increase in economic multipliers (Campbell, 1999; Wild et al., 1994). The food and beverage, accommodation, and handicraft industries were among the more popular sectors supporting the development. Many traditional industries can be developed and improved in response to the increased demand following tourism development (Macdonald \& Jolliffe, 2003).

Consequently rural tourism serves a channel for socio-economic development and revival. As a rising sector in the overall tourism market (Sharpley, 2000) and a significant source of income and employment for rural 
economies (Hummelbrunner \& Miglbauer, 1994), rural tourism amplifies the quality of life of local communities (Simpson et al., 1998) and stimulates flagging rural economies (Din, 1993). Respondents were positive toward tourism development, most being willing to support tourism development so long as they are given the opportunity be involved in tourism-based activities. This desire to exert some control over the tourism development, and to be more aware of tourism, helps the local community to influence the course of development in the area.

Furthermore, the respondents recognized other positive effects of tourism development, including the creation of new business opportunities, promoting entrepreneurship, increasing household income, better roads, electricity, and other forms of infrastructure. Most of the respondents indicated that rural tourism positively affected the development of the local area.

This study ascertained the relationship between tourism development and local community participation. Thongma et al. (2011) reported that the participation of local communities was instrumental to the success of rural tourism development because locals build strong relationships with tourists and impress visitors with local cultural activities. Community participation also gives locals the opportunity to participate in development activities, empowers them to mobilize their capabilities in managing their resources, enables them to make decisions, and to exert some control over activities that affect their lives.

To that end, our findings demonstrated the interest of the local community to engage in decision making, planning, and tourism development. Inskeep (1991) proposed that the local community should be involved in tourism activities and that the greater their involvement the greater their socio-economic benefits are from tourism. Through the involvement of local communities in decision-making processes, traditional lifestyles and values are respected (Sheldon \& Abenoja, 2001; Tosun, 2000). With the establishment of any kind tourism there exists the possibility to supplement traditional sources of income.

However, in our study, it became apparent that tourism benefits, and even employment opportunities, were narrowly distributed across the locality. Tourism can be an effective means of development; however, historically tourism has not always been well integrated into the development strategies of rural communities. As a result, tourism often becomes an unfulfilled promise in terms of the creation of indigenous employment and a supplementary source of household income. Benefits to rural residents, both in economic and social terms, become minimal where there is a lack of local involvement in tourism development, or where locals are unable to or prevented from responding to the employment opportunities arising through tourism. Mowforth and Munt (2008), therefore, advocate for community participation in the context of sustainable tourism. Hall (2008) adds that successful tourism planning entails the involvement and participation of residents in the area. And Mancini et al. (2003) suggests that the local community plays a pivitol role in the lives of its members by promoting their physical, social, psychological, and spiritual well-being.

\section{Conclusion}

In this study, we investigated the involvement of the local community surrounding Kinabalu National Park in rural tourism development and the benefits of tourism for the host community. It is clear from this case study that local participation is a natural outcome of completed tourism projects and that tourism is an effective respons to many rural problems. Furthermore, the benefits of tourism encourage local communities to participate in tourism development programs. In Malaysia's rural communities, where there is a strong adherence to cultural and religious observances, tourism development training for local residents should include the inculcation of cultural tolerance and an appreciation of cultural differences.

In conclusion, even if local people regard a tourism development in their area positively, government and other stakeholders should still emphasize the benefits of community involvement. To this end, the government should aim to create opportunities and programs to help the community embrace a range of tourism products relevant and beneficial to the development of the local area. Furthrmore, stakeholders should look to provide monetary assistance, perhaps through crediting or micro-loan systems, to empower the local communities to realize the opportunities created by the rural tourism development.

\section{References}

Azman, N., Halim, S. A., Liu, O. P., \& Komoo, I. (2011). The Langkawi Global Geopark: local community's perspectives on public education. International Journal of Heritage Studies, 17(3), 261-279. http://dx.doi.org/10.1080/13527258.2011.557863

Backhaus, N. (2003). Non-place jungle: The construction of authenticity in National parks of Malaysia. Indonesia and the Malay World, 31(89), 151-160. http://dx.doi.org/10.1080/13639810304438 
Beedie, P., \& Hudson, S. (2003). Emergence of mountain-based adventure tourism. Annals of Tourism Research, 30(3), 625-643. http://dx.doi.org/10.1016/S0160-7383(03)00043-4

Campbell, L. M. (1999). Ecotourism in rural developing communities. Annals of Tourism Research, 26(3), 534-553. http://dx.doi.org/10.1016/S0160-7383(99)00005-5

Chaudhry, P., \& Gupta, R. K. (2010). Urban greenery and its sustainable extension strategies in hot arid region of India. International Journal of Sustainable Society, 2(2), 146-155. http://dx.doi.org/10.1504/IJSSoc.2010.033627

Chaudhry, P., \& Gupta, R. K. (2010). Urban greenery and its sustainable extension strategies in hot arid region of India. International Journal of Sustainable Society, 2(2), 146-155. http://dx.doi.org/10.1504/IJSSoc.2010.033627

Claiborne, C. (2010). Community participation in tourism development and the value of social capital-The case of Bastimentos, Bocas del Toro, Panamá (Master's thesis, University of Gothenburg, Gothenburg, Sweden). Retrieved from http://ejournal.narotama.ac.id/files/Community\%20Participation\%20in\%20Tourism\%20Development\%20a nd\%20the\%20Value\%20of\%20Social\%20Capital.pdf

Din, K. (1993). Dialogue with hosts: An educational strategy towards sustainable tourism. In M. Hitchcock, V. King, \& M. Parnwell (Eds.), Tourism in South-East Asia (pp. 328-336). London, United Kingdom: Routledge.

Eruera, A. (2008). Rural tourism development in the eastern Hokianga area (Master's thesis, Auckland University of Technology, Auckland, New Zealand). Retrieved from http://aut.researchgateway.ac.nz/bitstream/handle/10292/540/ErueraA.pdf?sequence=4\&isAllowed=y

Fleischer, A., \& Pizam, A. (1997). Rural tourism in Israel. Tourism Management, 18(6), 367-372. http://dx.doi.org/10.1016/S0261-5177(97)00034-4

Frederick, M. (1993). Rural tourism and economic development. Economic Development Quarterly, 7(2), 215-224. http://dx.doi.org/10.1177/089124249300700207

Gale, T. E. (2006). Finding meaning in sustainability and a livelihood based on tourism: An ethnographic case study of rural citizens in the Aysén region of Chile (Doctoral dissertation). Retrieved from ProQuest Dissertations and Theses database.

Geoffrey, L. R., \& Nepal, S. K. (2010). Dependency and development in northern Thailand. Annals of Tourism Research, 37(4), 947-968. http://dx.doi.org/10.1016/j.annals.2010.03.005

Ghaderi, Z., \& Henderson, J. C. (2012). Sustainable rural tourism in Iran: A perspective from Hawraman village. Tourism Management Perspectives, 2, 47-54. http://dx.doi.org/10.1016/j.tmp.2012.03.001

Gurung, C. P., \& DeCoursey, M. A. (2000). Too much too fast: lessons from Nepal's Lost Kingdom of Mustang. In P. M. Price, M. F. Price, \& F. M. Zimmerman (Eds.), Tourism and Development in Mountain Regions (pp. 239-253). New York, NY: CABI Publishing.

Hall, C. M. (1994). Tourism and politics: Policy, power and place. Hoboken, NJ: John Wiley \& Sons.

Hall, C. M. (2008). Tourism planning: Policies, processes and relationships. Upper Saddle River, NJ: Pearson Education.

Hall, D. (2004). Rural tourism development in southeastern Europe: Transition and the search for sustainability. International Journal of Tourism Research, 6(3), 165-176. http://dx.doi.org/10.1002/jtr.482

Harrison, D., \& Schipani, S. (2007). Lao tourism and poverty alleviation: Community-based tourism and the private sector. Current Issues in Tourism, 10(2-3), 194-230. http://dx.doi.org/10.2167/cit310.0

Hasegawa, M., Ito, M., \& Kitayama, K. (2006). Community structure of oribatid mites in relation to elevation and geology on the slope of Mount Kinabalu, Sabah, Malaysia. European Journal of Soil Biology, 42, S191-S196. http://dx.doi.org/10.1016/j.ejsobi.2006.07.006

Horowitz, L. S. (1998). Integrating indigenous resource management with wildlife conservation: A case study of Batang Ai National Park, Sarawak, Malaysia. Human Ecology, 26(3), 371-403. http://dx.doi.org/10.1023/A:1018752115074

Hummelbrunner, R., \& Miglbauer, E. (1994). Tourism promotion and potential in peripheral areas: The Austrian case. Journal of Sustainable Tourism, 2(1-2), 41-50. http://dx.doi.org/10.1080/09669589409510682 
Inskeep, E. (1991). Tourism planning: An integrated and sustainable development approach. London, United Kingdom: Van Nostrand Reinhold.

Iorio, M., \& Corsale, A. (2010). Rural tourism and livelihood strategies in Romania. Journal of Rural Studies, 26(2), 152-162. http://dx.doi.org/10.1016/j.jrurstud.2009.10.006

Jaafar, M., Kayat, K., Tangit, T. M., \& Yacob, M. F. (2013). Nature-based rural tourism and its economic benefits: A case study of Kinabalu National Park. Worldwide Hospitality and Tourism Themes, 5(4), 342-352. http://dx.doi.org/10.1108/WHATT-03-2013-0016

Keane, M. (1992). Rural tourism and rural development. In H. Briassoulis and J. van der Straaten (Eds.), Tourism and the Environment (pp. 43-55). New York, NY: Springer.

Khalifah, Z., \& Tahir, S. (1997). Malaysia: Tourism in Perspective. In F. M. Go, \& C. L. Jenkins (Eds.), Tourism and Economic Development in Asia and Australasia (pp. 176-196). Cassell: London

Lacher, R. G., \& Nepal, S. K. (2010). From leakages to linkages: Local-level strategies for capturing tourism revenue in Northern Thailand. Tourism Geographies, 12(1), 77-99. http://dx.doi.org/10.1080/14616680903493654

Lama, W.B., \& Sattar, N. (2004). Mountain tourism and the conservation of biological and cultural diversity. In M.F. Price, L. Jansky, \& A.A. Iatsenia (Eds.), Key issues for mountain areas (pp.111-148). Tokyo: United Nations University Press.

Lane, B. (1994). What is rural tourism? Journal of Sustainable Tourism, 2(1-2), 7-21. http://dx.doi.org/10.1080/09669589409510680

Liu, A. (2006). Tourism in rural areas: Kedah, Malaysia. Tourism Management, 27(5), 878-889. http://dx.doi.org/10.1016/j.tourman.2005.05.007

Lo, M. C, Songan, P, Mohamad, A. A. \& Yeo, A. W. (2013). Rural tourism and destination image: Community perception in tourism planning. The Macro-theme review, 2(1), 102-118.

MacDonald, R., \& Jolliffe, L. (2003). Cultural rural tourism: Evidence from Canada. Annals of Tourism Research, 30(2), 307-322. http://dx.doi.org/10.1016/S0160-7383(02)00061-0

Mancini, J. A., Martin, J. A., \& Bowen, G. L. (2003). Community capacity. In T. P. Gulotta \& M. Bloom (Eds.), Encyclopedia of Primary Prevention and Health Promotion (pp. 319-330). NY: Kluwer Academic/Plenum.

Maryati, M., Azizah, H., \& Arbain, K. (1996). Terrestrial ants (Hymenoptera: Formicidae) of Poring, Kinabalu Park, Sabah. Tropical Rainforest Research-Current Issues, 74, 117-123. http://dx.doi.org/10.1007/978-94-009-1685-2_11

May-Ling, S., Ramachandran, S., Shuib, A., \& Afandi, S. H. M. (2014). Barriers to community participation in rural tourism: A case study of the communities of Semporna, Sabah, Malaysia. Life Science Journal, 11(11), 837-841.

Moss, L. A., \& Godde, P. M. (2000). Strategy for future mountain tourism. In P. M. Price, M. F. Price, \& F. M. Zimmerman (Eds.), Tourism and Development in Mountain Regions (pp. 323-338). New York, NY: CABI Publishing.

Mowforth, M., \& Munt, I. (2008). Tourism and sustainability: Development, globalisation and new tourism in the third world (3rd ed.). New York, NY: Taylor \& Francis.

Nepal, S. K., \& Chipeniuk, R. (2005). Mountain tourism. Toward a conceptual framework. Tourism Geographies: An International Journal of Tourism Space, Place and Environment, 7(3), 313-333. http://dx.doi.org/10.1080/14616680500164849

Nunkoo, R., \& Gursoy, D. (2012). Residents' support for tourism: An identity perspective. Annals of Tourism Research, 39(1), 243-268. http://dx.doi.org/10.1016/j.annals.2011.05.006

Okazaki, E. (2008). A community-based tourism model: Its conception and use. Journal of Sustainable Tourism, 16(5), 511-529. http://dx.doi.org/10.1080/09669580802159594

Okech, R., Haghiri, M., George, B. P., George, B., \& Korstanje, M. (2012). Rural tourism as a sustainable development alternative: An analysis with special reference to Luanda, Kenya. Cultur: Revista De Cultura e Turismo, 6(3), 36-54.

Petric', L. (2003). Constraints and possibilities of the rural tourism development with the special stress on the case of Croatia. Ersa 2003 Congress. University of Jyva"skyla”, Finland. Retrieved from 
http://ideas.repec.org/p/wiw/wiwrsa/ersa03p105.html, retrieved in October 2008

Scheyvens, R. (1999). Ecotourism and the empowerment of local communities. Tourism Management, 20(2), 245-249. http://dx.doi.org/10.1016/S0261-5177(98)00069-7

Scheyvens, R. (2002). Tourism for development: Empowering communities. Upper Saddle River, NJ: Pearson Education.

Sharpley, R. (2000). Tourism and sustainable development: Exploring the theoretical divide. Journal of Sustainable Tourism, 8(1), 1-19. http://dx.doi.org/10.1080/09669580008667346

Sharpley, R. (2002). Rural tourism and the challenge of tourism diversification: The case of Cyprus. Tourism Management, 23(3), 233-244. http://dx.doi.org/10.1016/S0261-5177(01)00078-4

Sharpley, R., \& Sharpley, J. (1997). Rural tourism. An introduction. Mumbai, India: International Thomson Business Press.

Sheldon, P. J., \& Abenoja, T. (2001). Resident attitudes in a mature destination: The case of Waikiki. Tourism Management, 22(5), 435-443. http://dx.doi.org/10.1016/S0261-5177(01)00009-7

Shukor, N. (2001). Elevational diversity patterns of small mammals on Mount Kinabalu, Sabah, Malaysia. Global Ecology and Biogeography, 10(1), 41-62. http://dx.doi.org/10.1046/j.1466-822x.2001.00231.x

Simpson, F., Chapman, M., \& Mahne, L. (1998). Partnership approaches to tourism and rural development in post-socialist Europe: The experience of Notranjski Kras, Slovenia. Paper Presented at the Rural Tourism Management: Sustainable Options International Conference, Auchincruive, Scotland, Sep. 1998.

Stepp, J. R. (2000). Mountain ethnobiology and development in highland Chiapas, Mexico: Lessons in biodiversity and health. Mountain Research and Development, 20(3), 218-219. http://dx.doi.org/10.1659/0276-4741(2000)020[0218:MEADIH]2.0.CO;2

$\mathrm{Su}$, B. (2011). Rural tourism in China. Tourism Management, 32(6), 1438-1441. http://dx.doi.org/10.1016/j.tourman.2010.12.005

Suh, Y. K., \& Gartner, W. C. (2004). Preferences and trip expenditures-A conjoint analysis of visitors to Seoul, Korea. Tourism Management, 25(1), 127-137. http://dx.doi.org/10.1016/S0261-5177(03)00056-6

Telfer, D. J., \& Sharpley, R. (2007). Tourism and development in the developing world. New York, NY: Routledge.

Thongma, W., Leelapattana, W., \& Hung, J.-T. (2011). Tourists'satisfaction towards tourism activities management of Maesa community, Pongyang sub-district, Maerim district, Chiang Mai province, Thailand. Asian Tourism Management, 2(1), 86-94.

Tosun, C. (2000). Limits to community participation in the tourism development process in developing countries. Tourism Management, 21(6), 613-633. http://dx.doi.org/10.1016/S0261-5177(00)00009-1

Wild, C. (1994) Issues in Ecotourism. In C.P. Cooper and A. Lockwood (Eds.) Progress in Tourism, Recreation and Hospitality Management (pp. 12-21). Chichester: John Wiley.

\section{Copyrights}

Copyright for this article is retained by the author(s), with first publication rights granted to the journal.

This is an open-access article distributed under the terms and conditions of the Creative Commons Attribution license (http://creativecommons.org/licenses/by/3.0/). 